\title{
SHARING SESSION WITH SCHOLARSHIP AWARDEE UNTUK MEMPERSIAPKAN MAHASISWA MELANJUTKAN STUDI
}

\author{
Fitri Aida Sari \\ Universitas Banten Jaya, Jl. Syech Nawawi Albantani Serang Banten, Indonesia \\ Email: fitriaidasari@unbaja.ac.id
}

\begin{abstract}
Education needs to be owned by every citizen to bring change for himself, society, country, and the world. To ensure that every citizen gets a proper and appropriate education, the state guarantees its citizens to get an education. This is stated in Pasal 31 Undang - Undang Dasar 1945. The implementation is reflected in free education starting from the Elementary School to the High School and Vocational High School. It does not stop there, even now the state provides various scholarships to facilitate citizens to obtain higher education. One of the scholarships offered is LPDP scholarship. LPDP is an Education Fund Management Institution that provides scholarships for the general public who wish to continue their studies at the tertiary level. Cirebon University, especially in the mathematics education study program, wants to prepare their students to achieve higher education. Therefore, the head of mathematics program, lecturers, and student association held a sharing session with the theme of getting your scholarship, continue your studies, and make your dreams come true. The purpose of this activity is to provide experience and motivation for students to continue their studies. The method in this activity is in the form of discussions with awardee of LPDP schoolarship both master and doctoral levels. The results of this activities showed that students had great enthusiasm to continue their studies and increased enthusiasm for obtaining scholarships both at domestic dan overseas.
\end{abstract}

Keywords: Education; Scholarship; LPDP; Sharing Sessions.

\begin{abstract}
ABSTRAK
Pendidikan perlu dimiliki oleh setiap warga negara untuk membawa perubahan baik untuk dirinya sendiri, masyarakat, negara, maupun dunia. Untuk memastikan setiap warganya memperoleh pendidikan yang layak dan tepat maka negara menjamin warganya untuk memperoleh pendidikan. Hal ini tertuang pada Pasal 31 Undang - Undang Dasar 1945. Implementasi dari pasal tersebut tercermin dalam pendidikan tanpa biaya mulai dari tingkat Sekolah Dasar (SD) hingga tingkat Sekolah Menengah Atas (SMA) dan Sekolah Menengah Kejuruan (SMK). Tidak sampai disana bahkan saat ini negara menyediakan berbagai beasiswa untuk memfasilitasi warga negaranya memperoleh pendidikan yang lebih tinggi. Salah satu beasiswa yang ditawarkan yaitu beaiswa LPDP. LPDP merupakan Lembaga Pengelola Dana Pendidikan yang menyediakan beasiswa bagi masyarakat secara umum yang ingin melanjutkan studi ke jenjang perguruan tinggi. Universitas Cirebon khususnya pada program studi pendidikan matematika ingin mempersiapkan mahasiswanya untuk mencapai pendidikan di jenjang yang lebih tinggi lagi. Oleh sebab itu, ketua program studi beserta dosen-dosen prodi pendidikan matematika yang dibantu oleh himpunan mahasiswa pendidikan matematika menyelenggarakan sebuah sharing session bertemakan raih beasiswamu, lanjutkan studimu, wujudkan mimpimu. Tujuan kegiatan ini adalah untuk memberikan pengalaman dan motivasi bagi mahasiswa untuk melanjutkan studi. Metode dalam kegiatan ini berupa diskusi dan tanya jawab dengan narasumber yang merupakan peraih beasiswa LPDP baik pada tingkat magister maupun doctoral. Hasil dari kegiatan pengabdian yang dilakukan menunjukan mahasiswa memiliki antusias yang besar untuk melanjutkan studi dan meningkatnya semangat untuk memperoleh beasiswa baik di dalam maupun luar negeri.
\end{abstract}

Kata Kunci: Pendidikan; Beasiswa; LPDP; Sharing Session. 


\section{PENDAHULUAN}

Pendidikan merupakan proses berkelanjutan yang dilakukan sebagai upaya dalam menciptakan manusia baik dari sisi lahir maupun batin (Sujana, 2019). Pendidikan juga dapat dijadikan sebagai media yang efektif dalam mengajarkan norma dan nilai di masyarakat (Kadi \& Awwaliyah, 2017). Pendidikan menjadi salah satu hal penting yang perlu diperoleh oleh setiap warga negara. Pendidikan dianggap penting karena dipercaya dapat membawa suatu negara menjadi negara yang maju, tanpa adanya pendidikan, suatu negara akan menjadi negara yang tertinggal baik dalam segi sumber daya manusia maupun kemajuan teknologi.

Pentingnya pendidikan juga diyakini oleh Negara Indonesia, Hal ini tertuang dalam Undang Undang Dasar 1945 Pasal 31 yang menyatakan bahwa setiap warga negara berhak untuk memperoleh pendidikan dimana ada kewajiban bagi warga negara untuk mengikuti pendidikan dasar dan pemerintah memiliki kewajiban untuk membiayainya. Pada pasal tersebut juga dijelaskan bahwa terdapat anggaran khusus yang digunakan untuk keperluan pendidikan yaitu sekurang-kurangnya dua puluh persen dari anggaran pendapatan dan belanja negara serta dari anggaran pendapatan daerah dan belanja daerah.

Implementasi dari UUD 1945 Pasal 31 tersebut menghadirkan sekolah-sekolah gratis tanpa adanya pungutan biaya untuk proses pembelajaran yang dilakukan. Mulai dari sekolah dasar sampai dengan sekolah menengah atas saat ini sudah mendapatkan dana Bantuan Operasional Sekolah atau yang lebih banyak dikenal dengan sebutan dana BOS. Dana BOS digunakan untuk mendanai belanja nonpersonalia bagi pendidikan di tingkat dasar dan menengah sebagai pelaksana program wajib belajar (Direktorat Sekolah Dasar, 2021). Dengan adanya dana BOS maka orang tua siswa tidak perlu khawatir lagi untuk menyekolahkan anaknya sampai di tingkat Sekolah Menengah Atas (SMA) atau Sekolah Menengah Kejuruan (SMK) karena semua pembiayaan sudah ditanggung oleh pemerintah. Namun lain hal nya jika orang tua menginginkan anaknya untuk melanjutkan pendidikan ke jenjang yang lebih tinggi misalnya untuk melanjutkan ke jenjang perguruan tinggi. Saat ini pemerintah belum mengalokasikan dana bagi seluruh rakyatnya untuk menempuh pendiidkan di jenjang perguruan tinggi.

Namun, hal ini bukan berarti bahwa tidak ada dana yang memang pemerintah sediakan dalam mendukung pendidikan di jenjang perguruan tinggi. Pemerintah menyediakan dana bantuan bagi masyarakat yang memiliki keterbatasan keuangan namun berprestasi dan memiliki keinginan untuk melanjutkan studi. Salah satunya adalah bantuan yang berada di bawah nauangan kementrian keuangan yaitu beasiswa Lembaga Pengelola Dana Pendidikan (LPDP). LPDP menyediakan beasisiswa bagi masyarakat secara umum yang ingin melanjutkan studi ke jenjang perguruan tinggi. Pada awalnya LPDP hanya menyediakan beasiswa untuk studi di 
tingkat S2 (magister) dan S3 (doktoral) baik di dalam negeri maupun luar negeri (LPDP, 2021). Namun pada tahun 2021 LPDP juga menyediakan berbagai beasiswa yang juga mencakup beasiswa di tingkat $\mathrm{S} 1$ yang bekerjasama dengan Kemendikbud.

Lain halnya dengan pendidikan dasar sampai dengan pendidikan menengah atas yang mana setiap orang dapat memperolehnya. Untuk memperoleh beasiswa LPDP ini memerlukan berbagai persyaratan dan persiapan yang matang bagi masyarakat yang ingin mendapatkannya karena sesuai dengan visi LPDP yaitu untuk menyiapkan SDM yang berdaya saing global, maka LPDP akan menyeleksi penerima beasiswa yang memang pantas untuk mendapatkan pendanaan tersebut.

Untuk dapat mempersiapkan mahasiswanya memperoleh beasiswa LPDP, Program Studi Pendidikan Matematika Universitas Muhammadiyah Cirebon mengadakan suatu sharing session dengan mengundang dua orang pembicara yang merupakan penerima beasiswa LPDP. Pembicara pertama merupakan salah satu penerima beasiswa doctoral LPDP pada tahun 2019 dan pembicara yang kedua merupakan penerima beasiswa magister pada tahun 2016.

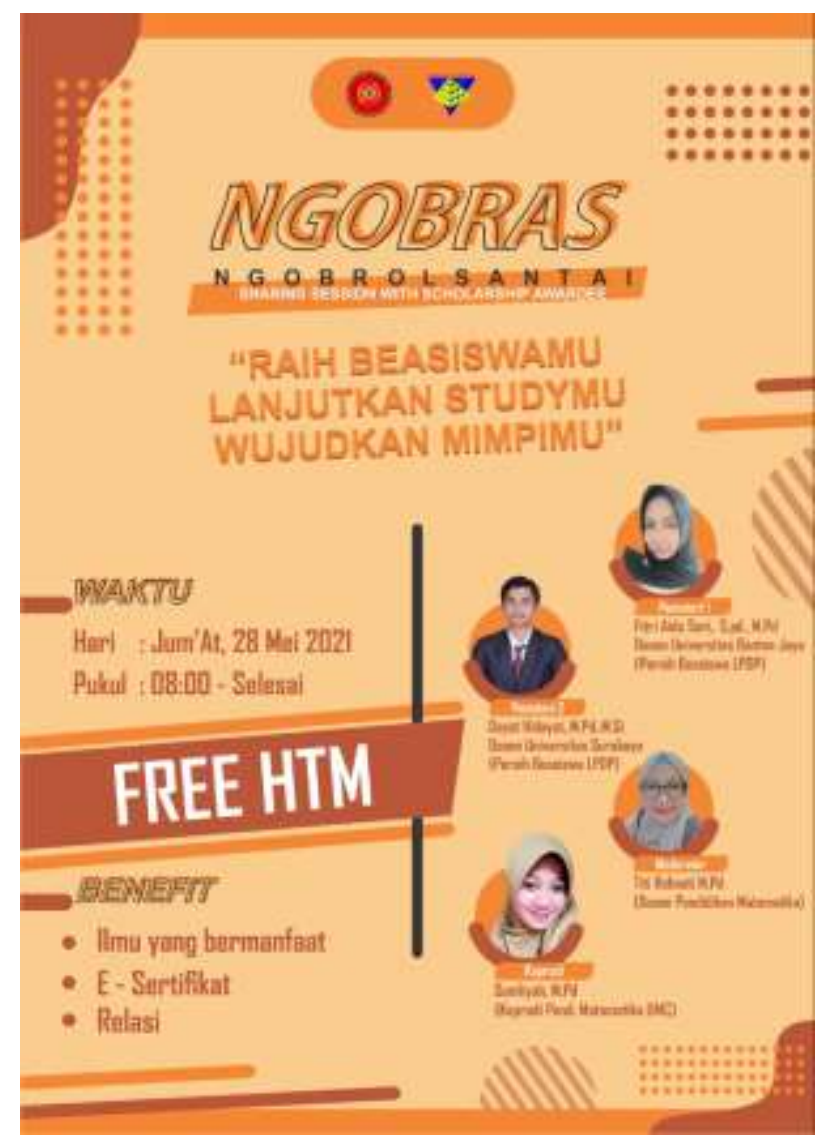

Gambar 1. Poster Acara Sharing Session 
Pada kegiatan tersebut, kedua pemateri membagi pengalaman, cara mendaftar sampai dengan kiat untuk memperoleh beasiswa LPDP. Pimpinan program Studi Pendidikan Matematika Universitas Muhammadiyah Cirebon berharap dengan diadakannya kegiatan tersebut maka mahasiswa dapat mempersiapkan segala berkas dan dokumen yang dibutuhkan untuk mendapatkan beasiswa LPDP dan mendapatkan pencerahan, motivasi serta pengalaman berdasarkan hasil pemaparan yang pemateri berikan.

\section{METODE}

Kegiatan diselenggarakan oleh program studi pendidikan matematika Universitas Muhammadiyah Cirebon yang dibantu himpunan mahasiswa pendidikan matematika Universitas Muhammadiyah Cirebon. Kegiatan diselenggaran pada hari Jumat tanggal 28 Mei 2021 Pukul 08.00 WIB sampai dengan 11.30 WIB. Kegiatan dilakukan secara online dengan bantuan aplikasi zoom yang disediakan oleh panitia dari Universitas Muhammadiyah Cirebon. Kegiatan diawali dengan pembukaan sekaligus sambutan yang diberikan oleh ketua program studi yakni Sumliyah, M.Pd kemudian dilanjutkan dengan materi yang disampaikan oleh Fitri Aida Sari, M.Pd yang merupakan salah satu penerima beasiswa LPDP di tingkat S3 (doktoral) dan Dayat Hidayat, M.Pd., M.Si yang merupakan penerima beasiswa LPDP di tingkat S2 (magister).

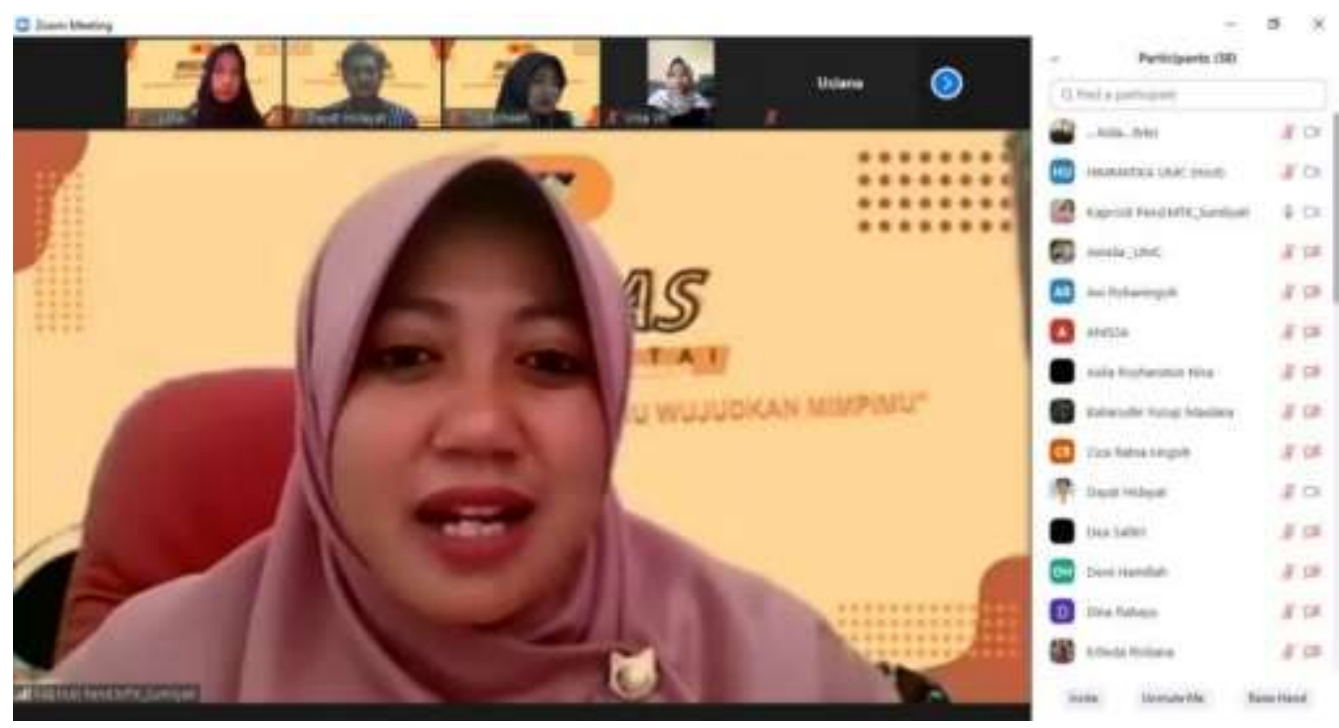

Gambar 2. Sambutan Kaprodi Pendidikan Matematika 
Sesi tanya jawab di moderator oleh salah satu dosen tetap program studi pendidikan matematika Universitas Muhammadiyah Cirebon yaitu Titi Rohaeti, M.Pd. Kegiatan ditutup dengan pesan yang disampaikan oleh tiap pemateri yang bertujuan untuk memberikan semangat bagi mahasiswa dalam mewujudkan mimpi dan cita-citanya dalam melanjutkan studi. Secara umum agenda kegiatan yang dilakukan adalah sebagai berikut:

Tabel 1. Agenda Acara Sharing Session

\begin{tabular}{|c|c|c|}
\hline Waktu & Kegiatan & Keterangan \\
\hline $08.00-09.00$ & Pembukaan dan sambutan & Sumliyah, M.Pd \\
\hline $09.00-09.30$ & Materi 1 & Fitri Aida Sari, M.Pd \\
\hline $09.30-10.00$ & Materi 2 & Dayat hidayat, M.Pd., M.Si \\
\hline $10.00-11.00$ & Diskusi dan tanya jawab & Titi Rohaeti, M.Pd \\
\hline $11.00-11.30$ & Penutup & Vina \\
\hline
\end{tabular}

\section{HASIL DAN PEMBAHASAN}

Kegiatan dilaksanakan kurang lebih dalam waktu tiga jam tiga puluh menit dimana terbagi atas sesi pemaparan materi dan sesi tanya jawab. Materi yang disampaikan pada acara sharing session diantaranya sebagai berikut:

\section{Pengenalan Gambaran Umum LPDP}

Pemateri memulai sharing dengan menjelaskan gambaran umum mengenai salah satu beasiswa yang diberikan oleh pemerintah Indonesia yaitu beasiswa LPDP. LPDP merupakan singkatan dari Lembaga Pengelola Dana Pendidikan, LPDP menyelenggarakan program beasiswa magister/doktor untuk putra-putri terbaik Indonesia. Seluruh warga negara Indonesia yang telah menyelesikan studi di tingkat Sarjana (S1) atau diploma empat (D4) dapat mendaftarkan dirinya mengikuti program beasiswa magister (S2) sedangkan bagi yang sudah menyelesaikan studi program magister (S2) dapat mendaftarkan dirinya mengikuti beasiswa program doctoral (S3). Tidak sampai disitu saja, pada tahun ini LPDP membuka beasiswa untuk jenjang S1 bagi putra putri Indonesia berprestasi untuk mendapatkan pendidikan tinggi baik di dalam maupun luar negeri. Untuk mengetahui informasi lebih lanjut tentang beasiswa LPDP, dapat diakses dengan mudah secara online pada situs https://www.lpdp.kemenkeu.go.id/in/home. 


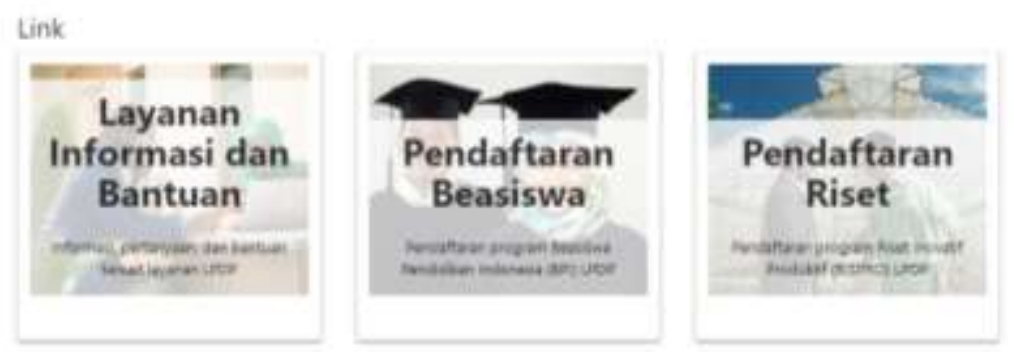

Gambar 3. Home Website LPDP

\section{Membaca dan Memahami Panduan Pendaftaran}

Sebelum mendaftarkan akun, ada hal-hal penting yang harus dipahami oleh siswa atau mahasiswa yang ingin mengikuti beasiswa. Oleh karena itu, mereka perlu untuk membaca dan memahami buku panduan yang disediakan. Sebagai contohnya, untuk beasiswa LPDP pada tahun 2021 secara umum terdapat tiga beasiswa yang ditawarkan diantaranya: 1 . Beasiswa Afirmasi yang terdiri dari beasiswa berkebutuhan khusus difabel, beasiswa daerah afirmasi, dan beasiswa prasejahtera; 2. beasiswa Tergeted yang terdiri dari beasiswa PNS, TNI, dan porli serta beasiswa kewirausahaan; 3. Beasiswa umum yang terdiri dari beasiswa regular, beasiswa PTUD dan beasiswa Co Funding. Setiap jenis beasiswa memiliki syarat umum dan syarat kusus tertentu sehingga buku panduan tersebut harus dipahami baik-baik. Siswa atau mahasiswa harus memilih beasiswa yang tepat dan beasiswa mana yang dapat mereka ikuti dalam artian bahwa semua syarat yang diminta dapat dipenuhi setelah itu barulah mereka dapat mengikuti beasiswa yang telah disediakan. Pada Gambar 4. dapat dilihat contoh buku panduan beasiswa LPDP pada program regular tahun 2021.

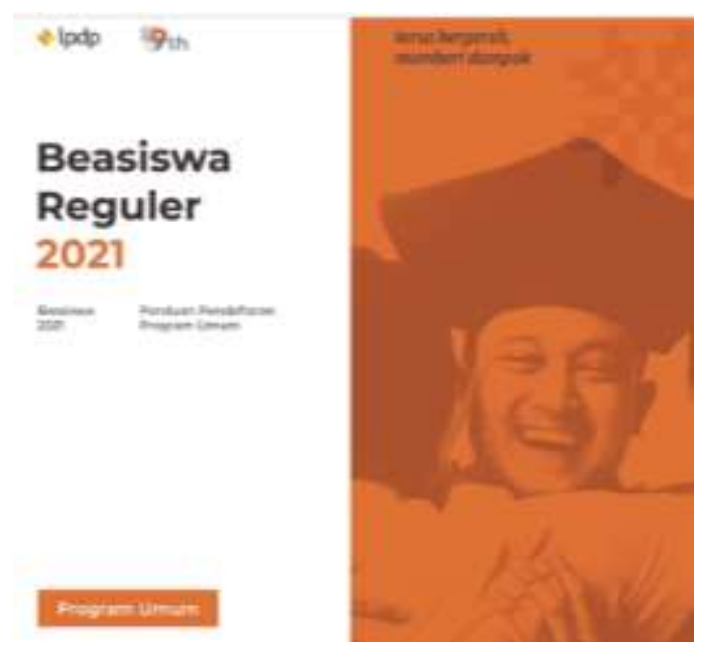

Gambar 4. Buku Panduan Beasiswa Reguler 
3. Mengecek Daftar Perguruan Tinggi Tujuan

Hal lain yang perlu pendaftar perhatikan adalah daftar perguruan tinggi tujuan. Baik perguruan tinggi dalam negeri maupun luar negeri, tidak semua perguruan tinggi dapat dijadikan sebagai tujuan untuk melanjutkan studi. terdapat kriteria-kriteria tertentu diantaranya untuk perguruan tinggi dalam negeri, maka akreditasi program studi dan akreditasi perguruan tinggi tersebut harus A bahkan untuk beasiswa PTUD hanya perguruan tinggi tertentu di luar negeri yang dapat dijadikan sebagai tempat studi. Contoh daftar perguruan tinggi tujuan untuk beasiswa PTUD adalah sebagai berikut:

\section{Daftar Perguruan Tinggi \\ Beasiswa PTUD tahun 2021}

\begin{tabular}{|c|l|c|c|}
\hline No & \multicolumn{1}{|c|}{ Nama Universitas } & Negara & Program Studi \\
\hline 1 & California Institute of Technology (Caltech) & Amerika Serikat & Semua \\
\hline 2 & Columbia University & Amerika Serikat & Semua \\
\hline 3 & Cornell University & Amerika Serikat & Semua \\
\hline 4 & Harvard University & Amerika Serikat & Semua \\
\hline 5 & Johns Hopkins University & Amerika Serikat & Semua \\
\hline 6 & Massachusetts Institute of Technology & Amerika Serikat & Semua \\
\hline 7 & Princeton University & Amerika Serikat & Semua \\
\hline 8 & Stanford University & Amerika Serikat & Semua \\
\hline 9 & Yale University & Amerika Serikat & Semua \\
\hline 10 & University of Cambridge & Inggris & Semua \\
\hline 11 & University of Oxford & Inggris & Semua \\
\hline 12 & ETH Zurich - Swiss Federal Institute of Technology & Swiss & Semua \\
\hline 13 & University of Pennsylvania & Amerika Serikat & Semua \\
\hline 14 & University of Chicago & Amerika Serikat & Semua \\
\hline 15 & University of California, Berkeley (UCB) & Amerika Serikat & Semua \\
\hline
\end{tabular}

\section{Gambar 5. Daftar PT pada Beasiswa PTUD}

\section{Pendaftaran Akun Beasiswa}

Jika ingin mendaftarkan diri di beasiswa LPDP sangatlah mudah. Pendaftaran dilakukan secara online dengan mengakses link https://beasiswalpdp.kemenkeu.go.id/. Saat ini LPDP bekerjasama dengan kemendikbud dalam memfasilitasi program beasiswa dengan menyediakan beasiasiswa yang disebut dengan Beasiswa Pendidikan Indonesia. Terdapat 7 
Jenis Beasiswa Pendidikan Indonesia yang disediakan diantaranya: 1. Beasiswa S2 atau S3 LPDP baik untuk pendidikan di dalam maupun luar negeri. Secara khusus apabila ingin mendaftar beasiswa LPDP maka siswa atau mahasiswa dapat memilih beasiswa ini dengan mengklik tombol berwarna bitu untuk mendaftar; 2. Beasiswa S1 atau D4 yang disediakan khusus untuk guru vokasi, pelaku budaya, siswa atau mahasiswa yang memiliki prestasi baik di tingkat nasional maupun internasional; 3. Beasiswa S2 atau S3 Dosen \& Beasiswa Joint Degree, beasiswa ini diperuntukkan bagi dosen perguruan tinggi. Pada walnya beasiswa ini masuk ke dalam kategori beasiswa LPDP targeted group atau beasiswa LPDP BUDI dalam dan luar negeri. Namun, sejak tahun 2021 beasiswa bagi dosen perguruan tinggi ini memiliki bagian tersendiri dalam Beasiswa Pendidikan Indonesia (BPI); 4. Beasiswa S2 aau S3 Non Dosen yang diperuntukkan khusus GTK, pelaku budaya dan mahasiswa berprestasi nasional untuk memperoleh beasiswa baik di dalam maupun luar negeri; 5. Beasiswa Non Degree Ditjen Dikti baik dalam dan luar negeri; 6. Beasiswa Non Degree Ditjen GTK; serta 7. Beasiswa Non Degree Ditjen Diksi.

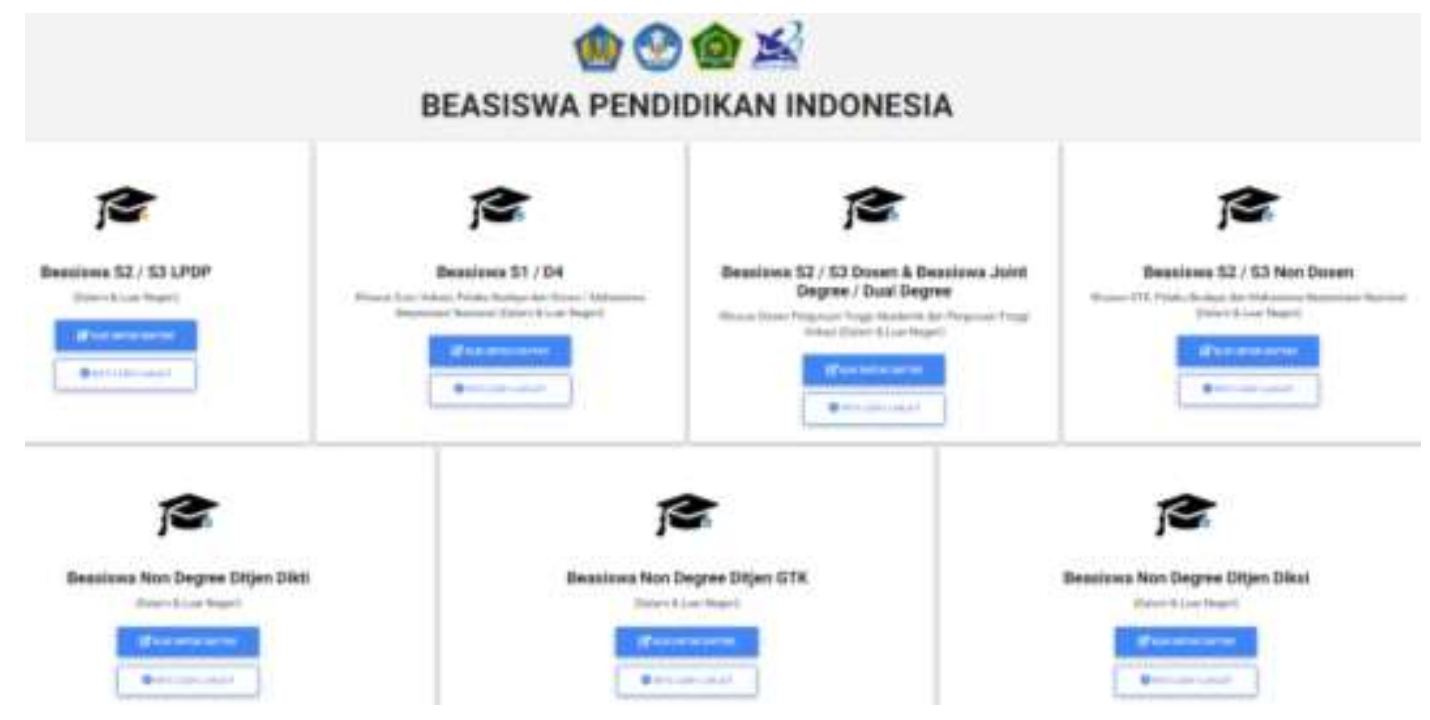

Gambar 6. Berbagai Jenis Beasiswa Pendidikan Indonesia (BPI)

Selanjutnya, sebagai contoh jika ingin mendaftar beasiswa LPDP maka dapat mengklik daftar dan akan muncul layar dimana kita diarahkan untuk memasukkan email dan password yang sudah didaftarkan. apabila belum memiliki akun maka dapat mengklik tulisan belum punya akun dan membuat akun baru. Untuk membuat akun baru, pendaftar akan diminta untuk memasukkan informasi seperti email, nama lengkap, nomor induk kependudukan, 
nomor kartu keluarga, tempat lahir, tanggal lahir, nomor handphone dan foto. Setiap orang hanya dapat membuat 1 akun dan tidak dapat membuat akun lainnya karena nomor induk kependudukan yang sudah didaftarkan disebuah akun, tidak dapat didaftarkan kembali di akun lainnya. Sehingga diharapkan setiap orang yang melakukan pendaftaran dapat mengingat akunnya masing-masing. Tampilan untuk log in dan registrasi akun baru dapat dilihat pada gambar di bawah ini:
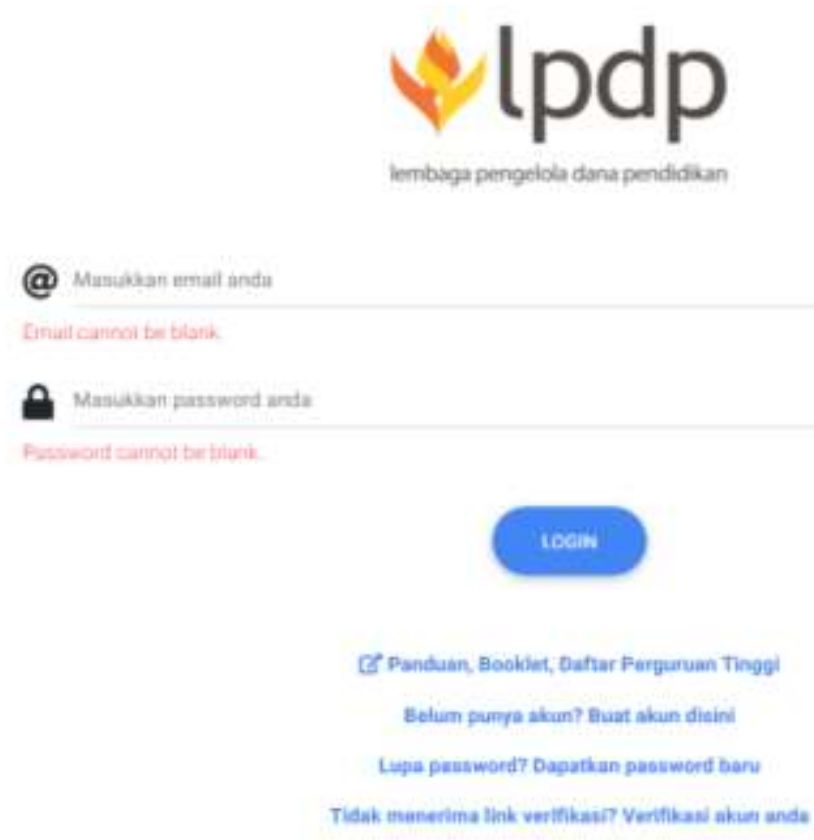

Gambar 7. Log In dan Registrasi Akun Beasiswa

5. Melengkapi Data Diri dan Mengunggah Persyaratan

Setelah log in maka akan muncul data lanjutan yang harus dilengkapi. Data yang perlu untuk dilengkapi mencakup: 1. Data diri seperti jenis kelamin, status menikah, alamat, dan jenis pekerjaan; 2. Media sosial baik facebook, twitter, maupun Instagram; 3. Pendiidkan terakhir yang berisi informasi mengenai Universitas asal, program studi, IPK terakhir, tahun lulus; 4. Data kelurga yang berisikan data ayah dan ibu dari pendaftar. Jika pendaftaran dilakukan dalam periode pembukaan beasiswa maka pendaftar dapat melanjutkan proses pendaftaran dengan mengunggah persyaratan yang dibutuhan. Dokumen yang diunggah harus disesuaikan dengan persyaratan yang diminta dari setiap jenis beasiswa karena perbedaan skema beasiswa yang dipilih memungkinkan adanya perbedaan persyaratan dokumen yang harus diunggah. Sebagai contoh untuk beasiswa LPDP pada skema regular berkas-berkas yang perlu untuk diunggah diantaranya: 1. Kartu Tanda Penduduk (KTP); 2. Ijazah; 3. 
Transkip nilai; 4. Sertifikat bahasa asing (maksimal 2 tahun dari tanggal dikeluarkannya sertifikat); 5. LOA diterima di perguruan tinggi tujuan; 6. Surat rekomendasi (dari atasan untuk yang sudah bekerja dan dari akademisi bagi yang belum bekerja); 7. Komitmen untuk kembali ke Indonesia (bagi pendaftar beasiswa luar negeri); 8. Proposal penelitian; dan lain sebagainya. Berkas persyaratan selengkapnya dapat dilihat pada gambar di bwah ini.

\begin{tabular}{|l|c|c|}
\hline \multicolumn{1}{|c|}{ Dokumen } & $\begin{array}{c}\text { Online } \\
\text { Form }\end{array}$ & $\begin{array}{c}\text { Unggahan } \\
\text { Dokumen }\end{array}$ \\
\hline Biodata Diri & $\checkmark$ & \\
\hline Kartu Tanda Penduduk (KTP) & & $\checkmark$ \\
\hline $\begin{array}{l}\text { ljazah S1/S2 (Asli atau Legalisir) } \\
\text { atau SKL (Surat Keterangan } \\
\text { Lulus) }\end{array}$ & & \\
\hline $\begin{array}{l}\text { Transkrip Nilai S1/S2 (Asli atau } \\
\text { Legalisir) }\end{array}$ & & \\
\hline $\begin{array}{l}\text { Sertifikat Bahasa Asing yang } \\
\text { dipersyaratkan dan Masih } \\
\text { Berlaku (Asli) }\end{array}$ & $\checkmark$ \\
\hline $\begin{array}{l}\text { Letter of Acceptance (LoA) } \\
\text { Unconditional yang masih } \\
\text { berlaku dan sesuai dengan } \\
\text { Perguruan Tinggi serta Program } \\
\text { studi yang dipilih }\end{array}$ & $\checkmark$ & $\checkmark$ \\
\hline $\begin{array}{l}\text { Surat Pernyataan sesuai format } \\
\text { LPDP (bermeterai) }\end{array}$ & & \\
\hline $\begin{array}{l}\text { Surat Rekomendasi dari } \\
\text { akademisi bagi yang belum }\end{array}$ & & \\
\hline $\begin{array}{l}\text { bekerja atau dari atasan bagi } \\
\text { yang sudah bekerja }\end{array}$ & & \\
\hline $\begin{array}{l}\text { Surat izin mengikuti seleksi dari } \\
\text { unit yang membidangi sumber } \\
\text { daya manusia bagi yang sedang } \\
\text { bekerja }\end{array}$ & & \\
\hline Profil Diri & & \\
\hline Personal Statement & \\
\hline $\begin{array}{l}\text { Komitmen kembali ke Indonesia } \\
\text { dan rencana kontribusi di } \\
\text { Indonesia pasca studi }\end{array}$ & & \\
\hline $\begin{array}{l}\text { Proposal Penelitian (khusus } \\
\text { Doktor) }\end{array}$ & & \\
\hline
\end{tabular}

\section{Gambar 8. Berkas Persyaratan yang Harus Diunggah}

6. Hal yang Perlu Dipersiapkan

Pada akhir materi, pemateri menyampaikan bahwa terdapat persyaratan yang perlu dipersiapkan dari jauh hari yaitu sertifikat bahasa asing dan LOA. Untuk memperoleh nilai 
bahasa asing yang sesuai dengan standar yang ditentukan, membutuhkan persipan belajar yang baik dan tekun sehingga perlu persiapan yang matang sebelum pendaftar melakukan tes untuk memperoleh sertifikat bahasa asing. Begitu juga dengan LOA, untuk dapat diterima di perguruan tinggi tujuan memerlukan persiapan sebelum dilaksanakannya tes masuk perguruan tinggi. Pendaftar akan bersaing dengan ratusan atau mungkin ribuan calon mahasiswa lainnya untuk memperoleh LOA dari perguruan tinggu yang dituju.

\section{KESIMPULAN}

Pendidikan merupakan aset penting yang wajib dimiliki oleh setiap orang. Saat ini, tidak ada hal yang bisa membatasi seseorang untuk dapat memperoleh pendidikan. Hal ini dikarenakan negara menjamin rakyatnya dalam memperoleh pendidikan. Berbagai beasiswa ditawarkan bagi putra - putri terbaik di Indonesia. Salah satu beasiswa yang menawarkan studi di tingkat perguruan tinggi mulai dari tingkat S1, S2 hingga jenjang S3 adalah beasiswa LPDP. Namun untuk memperoleh beasiswa tersebut tidaklah mudah, persyaratan yang dibutuhkan untuk dapat mendaftar cukuplah banyak dan berat sehingga dibutuhkan persiapan sebelum mengikuti beasiswa yang ditawarkan. Beberapa hal yang perlu dipersiapkan sebelum mengikuti beasiswa diantaranya: 1) Membaca dan memahami panduan pendaftaran; 2) Mengecek daftar perguruan tinggi tujuan; 3) Membuat akun beasiswa jika pendaftarannya dilakukan secara online; dan 4) Mempersipakan berkas-berkas yang diperlukan untuk melakukan pendaftaran. Oleh karena itu untuk mempersiapkannya dengan baik, dibutuhkan kegiatan seperti sharing session yang membahas persiapan mengikuti beasiswa dari narasumber yang pernah mengikuti seleksi dan lolos pada program beasiswa yang akan dituju.

\section{DAFTAR PUSTAKA}

Direktorat Sekolah Dasar. (2021). Bantuan Operasional Sekolah (BOS). Diakses dari http://ditpsd.kemdikbud.go.id/hal/bos.

Kadi, T., \& Awwaliyah, R. (2017). Inovasi Pendidikan: Upaya Penyelesaian Problematika Pendidikan di Indonesia. Jurnal Islam Nusantara, 1(2), 144-155. https://doi.org/10.33852/jurnalin.v1i2.32.

Lembaga Pengelola Dana Pendidikan. (2021). Kebijakan Beasiswa LPDP 2021. Diakses dari https://www.lpdp.kemenkeu.go.id/in/page/Beasiswa2021.

Sujana, I. W. C. (2019). Fungsi dan Tujuan Pendidikan Indonesia. Adi Widya: Jurnal Pendidikan Dasar, 4(1), 29. https://doi.org/10.25078/aw.v4i1.927.

Undang - Undang Dasar 1945 Pasal 31 Ayat 1 tentang Setiap Warga Negara Berhak Mendapatkan Pendidikan. 